\title{
Economic Diplomacy
}

Essays and Reflections

by Singapore's Negotiators 

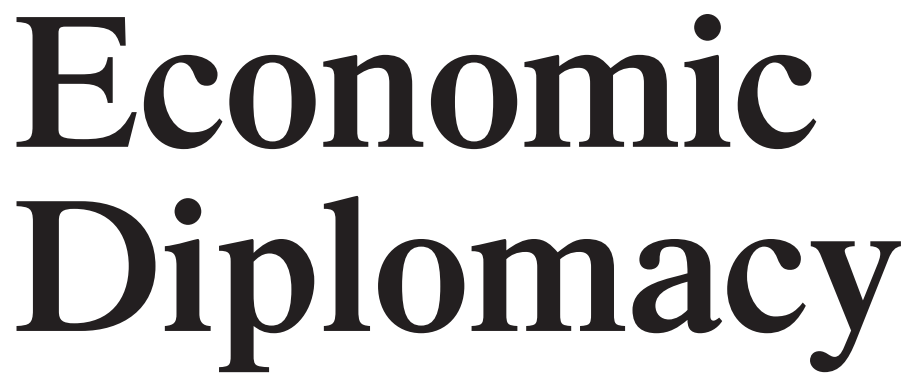

Essays and Reflections by Singapore's Negotiators

\section{L Lim}

University of Hong Kong, Hong Kong

Margaret Liang

Ministry of Foreign Affairs, Singapore 


\section{Published by}

World Scientific Publishing Co. Pte. Ltd.

5 Toh Tuck Link, Singapore 596224

USA office: 27 Warren Street, Suite 401-402, Hackensack, NJ 07601

UK office: 57 Shelton Street, Covent Garden, London WC2H 9HE

\section{Library of Congress Cataloging-in-Publication Data}

Economic diplomacy : essays and reflections by Singapore's negotiators / edited by C. L. Lim \& Margaret Liang. -- 1 st ed.

p. $\mathrm{cm}$.

ISBN-13: 978-9814324632

ISBN-10: 9814324639

1. Singapore--Foreign economic relations. 2. Diplomacy--History. I. Lim, C. L. (Chin L.)

II. Liang, Margaret.

HF1595.E26 2010

382.095957--dc22

2010037961

\section{British Library Cataloguing-in-Publication Data}

A catalogue record for this book is available from the British Library.

Cover illustration: Le travail dans l'abondance (mural) by Gustave-Louis Jaulmes (1873-1959), Centre William Rappard, Genève.

Copyright @ 2011 by World Scientific Publishing Co. Pte. Ltd.

All rights reserved. This book, or parts thereof, may not be reproduced in any form or by any means, electronic or mechanical, including photocopying, recording or any information storage and retrieval system now known or to be invented, without written permission from the Publisher.

For photocopying of material in this volume, please pay a copying fee through the Copyright Clearance Center, Inc., 222 Rosewood Drive, Danvers, MA 01923, USA. In this case permission to photocopy is not required from the publisher.

Typeset by Stallion Press

Email: enquiries@stallionpress.com

In-house Editor: Juliet Lee Ley Chin

Printed in Singapore.

National University of Singapore

Registration Number: 200604346E 
"As an open economy with a large share of exports in its GDP, Singapore has been keen to promote more openness in the international economy and has been active in formal and informal negotiations at the WTO to achieve greater consensus among members. The reflections in this book, offered by experienced Singaporean negotiators who have been at the frontline of regional and multilateral trade talks, vividly convey the process and dynamics of trade negotiations; they provide fascinating insights for any policy maker and negotiator working in the field."

Supachai Panitchpakdi, Secretary-General of UNCTAD

"The Singapore economic miracle is founded in no small part on Singapore's ability to ride the crest of globalisation. Singapore has faced the challenge of globalisation with both astute strategy and plucky self-reliance. As part of Singapore's strategy, it has developed a cadre of trade policy experts with extraordinary skill and experience. This remarkable volume brings together a group of these experts to offer the benefits of that skill and experience to the rest of the world. This essential book fascinates and informs, but also will play a critical role in preparing trade policy professionals from around the world."

Professor Joel P. Trachtman, Director, Hitachi Centre for Technology and International Affairs, Fletcher School of Law and Diplomacy

"Singapore has made a huge contribution to the development of the multilateral trading system, way beyond what might be envisaged from a nation of its relatively modest (if you will forgive the term) proportions. Why? Because strong multilateral rules tend to dilute the 'law of the jungle' and promote a more level playing field. How? Read this book and you will find out. It is because of the excellence of its negotiators (amply demonstrated in this book); because they master the substance; because they have earned and maintain widespread respect; and because they seek to build bridges. In the world of multilateral economic diplomacy, Singapore has proven time and again that influence does not depend on size. Long may it continue!"

Stuart Harbinson, former Chairman, WTO General Council

"The contributors to this collection provide a firsthand perspective of WTO/GATT and FTA negotiations. The result is a vivid, informed account of the evolution of global trade regimes, enhanced with a practitioner's view on the future. With its mix of technical articles and personal narratives of the negotiation processes, this volume is an invaluable resource for those interested in economic diplomacy and multilateral legal negotiations."

Tony Chew, Chairman, Singapore Business Federation

"This collection covers the whole range of international trade policy, bringing together the experience of the past with the perspectives of the future. It is a testimony to the great importance of smaller players in working for solutions and improvements in the multilateral context. Singapore is in the front row of the 'friends of the system', and the multilateral system is fortunate to have such friends."

Renato Ruggiero, former Director-General, WTO 


\section{CONTENTS}

Foreword $\quad$ ix

George Yeo

Foreword

xi

Lim Hng Kiang

Foreword

xiii

Khaw Boon Wan

xix

Letter

Renato Ruggiero

Preface

xxiii

C.L. Lim and Margaret Liang

About the Contributors $\quad$ XXV

Singapore's Economic Diplomacy: An Introduction 1

Barry Desker, Margaret Liang, C.L. Lim and

See Chak Mun

Part One: Essays and Reflections on Multilateralism

$\begin{array}{ll}\text { (A) Essays } & 21\end{array}$

Chapter 1 The WTO Institutional Reforms: Issues 23

and Prospects

See Chak Mun

Chapter 2 Informal Caucuses Within the WTO:

Singapore in the "Invisibles Group"

Barry Desker 
Chapter 3 Anti-Dumping Negotiations in the Uruguay

Round: Reflections of a Singapore Negotiator

Margaret Liang

Chapter 4 Intellectual Property Rights in the

Uruguay Round

S. Tiwari

Chapter 5 A New Approach to Trade Negotiations? Vanu Gopala Menon

Chapter 6 Domestic Regulations in Services:

A Chairman's Perspective

Peter Govindasamy

Chapter 7 Future Trends in Intellectual Property

and Impact on Trade and Development

Geoffrey $\mathrm{Yu}$

(B) Reflections

Chapter 8 My Experiences with the WTO Dispute

Settlement System

Tommy Koh

Chapter 9 The WTO Ministerial Conference

in Singapore

K. Kesavapany

Part Two: Essays and Reflections on Free Trade Agreements

(A) Essays

Chapter 10 An Intuitive Guide to the Services Chapter of the United States-Singapore Free Trade

Agreement

Ong Ye Kung

Chapter 11 Some Lessons from Past FTA Disputes C.L. Lim

Chapter 12 ASEAN's Journey Towards Free Trade 
Chapter 13 The Road to Free Trade Agreements

Ng Bee Kim and Minn Naing Oo

Chapter 14 Multilateral or Regional - WTO "and/or"

(B) Reflections

Chapter 15 The China-Singapore Free Trade Agreement Ng Bee Kim

Chapter 16 The Japan-Singapore Free Trade Agreement Pang Kin Keong

Annex

List of FTAs That Singapore is Party To

Glossary

Index 
This page is intentionally left blank 


\section{FOREWORD}

Trade is Singapore's lifeblood. It was for trade that Raffles established Singapore as an entrepôt for the British East India Company in 1819. That was in an earlier age of globalisation. Singapore will benefit greatly from a new age of globalisation in the 21st century. With the re-emergence of China and India on the global stage, a new East-West trade, creating new patterns of economic interdependence, is reshaping the civilisation of Maritime Asia.

Because trade is at the core of Singapore's economy, it is only to be expected that we favour trade liberalisation in any and every way possible. We support the WTO and its efforts at promoting multilateral trade. By promoting a rules-based multilateral trading system, the WTO enhances global governance. Even though the Doha Development Agenda is floundering and may take many more years to conclude, we must keep pushing in that direction. If we stop doing so, the forces of protectionism will push us in directions that are less advantageous, even dangerous, for us. This global financial crisis is bound to strengthen the forces of protectionism in every country.

The centrepiece of the Doha Development Agenda is liberalisation of agricultural markets. Because agriculture is rooted in the land and an inseparable part of the lives and cultures of billions of people, it is the most difficult sector to negotiate. Sometimes I wonder if we should not take a more practical approach and be less ambitious in our targets. Not having an agricultural sector ourselves, Singapore can afford to take a more detached view of the problem. Not so for many countries, however, where governments can collapse over farm issues.

The challenge of the future will be trade in services and knowledge products. Unlike agriculture, these are rootless and weightless like software, entertainment, financial services and biomedicine. For these new areas, a multilateral approach is impractical. Instead we need plurilateral 
agreement among the advanced economies where these new industries are concentrated. They in turn should be generous to the other economies. As Pascal Lamy once pointed out to me, for this New Economy, the key is trust. The recent worldwide collapse of trust in financial markets shows how critical that trust is even though it is intangible. We need trust to establish standards and security.

Looking ahead, the Asia Pacific will lead the world economy. To promote trade in the New Economy, we need to build trust and set high standards. Singapore's FTA strategy is to move early whenever and wherever possible, and to encourage others to come along, both by example and by competitive pressure. Strengthening economic integration in ASEAN is fundamental. All our bilateral FTAs are negotiated with the intention of bringing the rest of ASEAN along eventually.

It is crucial to conclude the Doha Round as soon as possible because so much is at stake, so much is being left on the table. Beyond Doha, however, the next round of trade liberalisation in the New Economy will have to be plurilateral, not multilateral. The Asia Pacific will have to lead the way to that future. It is a future which will bring prosperity to Singapore.

Recently, a bold new initiative has been launched to create a TransPacific Strategic Economic Partnership. It started with Singapore, New Zealand and Chile agreeing in 2002 to create a common platform of high standards which others could also plug into. After a few months, Brunei also joined in, creating the P4. In November 2008, the US, Australia and Peru asked to become members as well. Vietnam and others have indicated interest. This Trans-Pacific Partnership is the arrowhead that could eventually lead to an APEC-wide Free Trade Area of the Asia Pacific. The 21 APEC economies make up over half of global trade and global GDP. Though this enterprise will take many years to bring to fruition, it is of historic significance.

George Yeo

Minister for Foreign Affairs

Singapore 


\section{FOREWORD}

The evidence is unequivocal. Where countries are economically closed and decoupled from regional or global markets, one sees poverty and stagnation. Economic openness, on the other hand, has led many to growth and prosperity.

Singapore is testimony to this. We have benefited greatly from participating actively in the global economy. With our small market size and limited resources, Singapore could not and cannot afford to be insular. Our fortunes lie in our ability to navigate deftly through the ebbs and swells in the global economy and finding opportunities and niches for our companies and people.

With globalisation comes greater exposure to the changes on the world economic stage. This reality is especially evident in the financial turmoil which unfolded in 2008. What started as a subprime housing mortgage crisis in the United States developed into a global financial tsunami, impacting countries far beyond the United States, including Singapore.

During periods of economic downturn, the temptation to retreat and close markets is great. But this will only make a recession deeper and more prolonged. Instead, the key to recovery often depends greatly on countries' willingness to create conditions for investments and trade to continue to flow and grow.

The rules-based trading system of the World Trade Organisation has always served as a key buttress of economic stability for Singapore. Multilateral trade liberalisation has helped to improve the lives of millions over the past decade and it continues to play an important role in locking in trade liberalisation efforts and stimulating economic growth around the world. However, we should not take the WTO for granted. The WTO needs to stay relevant to the changing needs of its Members and the world through regular review of its processes and agenda.

While the multilateral WTO framework remains the bedrock of Singapore's trade policy, Singapore is also an active player in the region. 
The closer integration and realisation of the ASEAN Economic Community has always been a key goal for Singapore. Singapore can only benefit from a stronger and more prosperous ASEAN.

The resurgence of China and India has shifted the global economic map and pushed Asia to the forefront in the 21st century. $60 \%$ of the world's population live in Asia. A dynamic and rich Asia is a great asset not only to Singapore but to the entire global economy.

Alongside regional integration, fostering closer inter-regional linkages is another key pillar of Singapore's trade policy. Closer inter-regional ties bring about greater interest in the success of another region. This often opens up new opportunities and also leads to greater stability and predictability in relations which again benefits businesses and the people in the two regions. In this respect, the Asia-Pacific Economic Cooperation (APEC) has surprised on the upside. Since its genesis as an informal Ministerial level dialogue group with 12 members in 1989, APEC has grown to become an effective inter-governmental grouping in the world. Through the efforts of APEC, tariffs and trade barriers across the Asia Pacific have been reduced and costs of business transactions slashed. APEC is now exploring the idea of a Free Trade Area of the Asia Pacific. Many building blocks are being put in place to achieve this. One such foundation stone is the Trans-Pacific Strategic Economic Partnership. Its expansion beyond the original group of four countries - Brunei, Chile, New Zealand and Singapore - offers a platform for ideas/initiatives to be tested and later explored with the larger APEC group.

As we focus on trade liberalisation, we also believe in building up the institutional knowledge and capacities of our people to drive our economic growth. This publication contains the invaluable experiences, perspectives and insights of the key people who have participated in and shaped Singapore's trade policy and trade history. These writers have been involved in Singapore's participation at various international, regional and bilateral trade fora in the diplomatic, economic as well as academic fields.

I trust that you will find this collection an engaging and insightful read, and a library of priceless institutional knowledge of Singapore's trade development.

Lim Hng Kiang

Minister for Trade and Industry

Singapore 


\section{FOREWORD}

In 1995, I moved from the Prime Minister's Office to the Ministry of Trade and Industry to be its Permanent Secretary. I knew that one key assignment would be to help then MTI Minister Yeo Cheow Tong chair the inaugural WTO Ministerial Conference. Besides the huge logistical challenges of hosting a global conference, the substantive part of the conference would involve getting trade ministers to make political trade-offs in sensitive sectors. As this would be the first WTO Ministerial Conference, and given Singapore's reputation, there were high expectations that the conference would not merely be an organisational success, it would also help move the global trade agenda forward.

We knew the challenges and we took our responsibilities seriously.

While the conference would actually be run by the WTO Secretariat, we knew that we would not be merely an event organiser. As the host, we had to also help the WTO Director-General bridge gaps, forge consensus, clear misunderstanding, help educate, cajole and persuade. It was a tall order.

The first task was to identify our resources, able diplomats and trade negotiators who had a strong global network, enjoyed trust as honest brokers and who were also knowledgeable about trade issues. Singapore was lucky to have many, including Chew Tai Soo, Barry Desker, K. Kesavapany, Tommy Koh, Lee Tsao Yuan, Kishore Mahbubani, See Chak Mun and S. Tiwari. But we needed many more.

The inaugural WTO MC was to assess the implementation and review of the so-called "built-in agenda" of the Uruguay Round, which took seven and a half years to negotiate and ran into 550 pages of legal documents. We needed domain experts in all the major chapters if we were to help forge consensus and make a serious contribution.

We made an important decision to assemble a big team of officials, drawn from the major Ministries and to bring them up to speed on all the 
key trade issues. With the help of the WTO Secretariat, we organised many workshops, from Trade Policy 101 to more esoteric trade matters, like antidumping and countervailing duties, technical barriers to trade and sanitary and phytosanitary measures and the many sophisticated political complications of agricultural trade. Together with my colleagues, we went back to school, took part in most of the workshops and sat through the lectures and tutorials. It was a significant investment of time and resources but one which was absolutely necessary. Our efforts were noted and appreciated by the WTO Secretariat.

As a result, we expanded drastically our team of trade diplomats and brought them up to speed. Along the way, we enhanced our network with the WTO Secretariat and, through many durian and chilli crab parties, built strong bonds of friendship which would prove valuable in due course.

The inaugural WTO MC was held in Singapore, from 9 to 13 December 1996. It was an outstanding event. For many delegates, that was their first trip to Singapore and Singaporeans "wowed" them with our courtesy, hospitality and efficiency. For many heads of delegation, we achieved what we set out to do, which was to impress them as soon as they arrived, getting them to their hotel rooms within an hour of their planes touching down in Changi. This required careful organisation and excellent inter-agency coordination, and it was worth every cent of the extra effort. We strengthened inter-agency coordination and forged an effective "whole-of-government" (WOG) approach. The WOG approach would subsequently be honed into a major competency of the Singapore Government and repeatedly put to effective use when we tackled the Asian Financial Crisis, SARS and, more recently, Influenza A/H1N1.

Just as importantly, the inaugural WTO MC achieved more than merely reviewing the UR's implementation. It moved the multilateral trade agenda forward, with the establishment of four permanent working groups: transparency in government procurement, trade facilitation, trade and investment, and trade and competition, otherwise known as the "Singapore issues". As an additional bonus, many key WTO members including the US, the EU, Japan as well as Singapore signed on to the Agreement on Information Technology, covering more than $90 \%$ of world trade in IT products, and agreed to eliminate tariffs for IT products on an MFN basis. The inaugural WTO MC firmly established Singapore as a small but influential consensus builder at the WTO.

The successful hosting positioned Singapore for its next stage of trade policy development. Trade is our lifeline. Our external trade is more than 
three times our GDP. Our prosperity depends on gaining fair access to the global market. More than many other countries, we have much more at stake in working to avoid trade barriers and protectionist sentiments at international borders. We have worked tirelessly with like-minded countries to advance successive global trade rounds. But we are not purists and do not adopt an ideological approach. Knowing the limitations of global trade rounds and the increasing difficulties of forging ambitious trade liberalisation, we are among the early pioneers who saw a need to also forge bilateral FTAs. To us, such sub-regional FTAs and global trade rounds are not mutually exclusive. Indeed, for small countries, the two can be synergised, both to secure our domestic position, as well as to spur the global round.

We actively leveraged on APEC to translate our insights into practice. After the WTO, APEC is the most important trade policy forum for us. We are active players in APEC to help advance global trade issues. We also use APEC to negotiate and conclude many bilateral FTA deals.

That was how our first FTA with New Zealand was done. We were likeminded on this trade policy strategy and we pioneered a way forward. With growing confidence, we raised our ambition further, by attempting an FTA with Japan. This was followed in quick succession by the launch of the US-Singapore FTA (USSFTA) in 2000, and the European Free Trade Association-Singapore FTA (ESFTA) which was concluded in record time by November 2001.

The Japan negotiation was memorable because it was especially challenging. First, ideologically they had been against bilateral FTAs — the GATT/WTO had been their mantra for over 50 years. Second, there was a perception that the balance of benefits was lopsided as Japan was a huge economy, and ours tiny. Third, they had many sensitive sectors, especially agriculture, while ours was fully open. As the then MITI Vice Minister put it bluntly to our then Ambassador to Japan, Chew Tai Soo, "You are already naked, what else have you got to show?"

Nonetheless, we had the audacity to consider the impossible and put all our hearts into the venture. Ambassador Chew was indefatigable in lobbying the Japanese politicians. His reports of many visits to the Japanese politicians were fascinating. Slowly and patiently, we moved the ground. Of course, MITI itself was on the reform path, without which no outsider could change their ideology. Along the way, we made many friends, and helped Japan speed up its rethink on global trade issues. When we finally signed the FTA with Japan, it was a major trade policy achievement. 
Our FTA journey was also a testimony to the importance of being nimble and being able to seize the opportunities as they emerged. The best example of this was the launching of the USSFTA in Brunei, on 16 November 2000.

On 11 November 2000, five days before the APEC Summit, then US Trade Representative, Charlene Barshefsky stopped by Singapore en route to Brunei. At her call on MM Lee Kuan Yew, the strategic imperative behind a USSFTA was carefully articulated. The next day, at Barshefsky's request, a "four-eyes" meeting was arranged, between her and Minister George Yeo in Brunei. Barshefsky said that a USSFTA was "doable" within US President Clinton's remaining term in office. This was however a very short window, as Clinton was due to step down in January 2001.

On 14 November, at the APEC Leaders' welcome ceremony, then PM Goh Chok Tong invited Clinton for a golf game. Clinton accepted the offer and suggested that it be done that night. Officials from both sides scrambled to arrange one, especially since confirmation of the game was only received during the APEC dinner itself when the leaders were still eating! Tee-off time was scheduled at midnight. As the arrangements were being made, there was a thunderstorm. It was only ten minutes before the leaders proceeded to their tee box that the sky finally cleared. Clinton enjoyed himself. After the game, over coffee, Clinton noted that US and Singapore officials had been talking about a USSFTA. In a few sentences, PM Goh persuaded Clinton of the strategic importance of the USSFTA. Clinton responded that the USSFTA was "worth doing".

Over the next 18 hours, there was a flurry of activity, and interventions made at all levels, to turn President Clinton's verbal response that the USSFTA was "worth doing" into a formal joint announcement by both Leaders on the launch of the USSFTA in Brunei. I recount this incident briefly to show how critical it was to detect an opportunity and to seize it. History would have been very different if we had made a different assessment and adopted a different response during those critical five days in Brunei.

When I left MTI in 2001, to stand for election as a PAP candidate, MTI had completed or was negotiating FTAs with five partners: Australia, the European Free Trade Association, New Zealand, Japan and the US. I remember my many APEC counterparts expressing dismay to me: "How do you do it?" They had problems assembling even one FTA negotiating team, despite having an army of trade diplomats. I suppose being less endowed, we just have to try harder. 
And this is indeed the story of Singapore. Given our limitations, we have to make extraordinary efforts to secure our place in the sun. This was so in the past; this will continue to be so going forward.

Khaw Boon Wan Minister for Health Singapore 
This page is intentionally left blank 


\section{LETTER}

I was very pleased to be invited by Ambassador See Chak Mun to add some words of welcome to this excellent work. Its contents cover the whole range of international trade policy, multilateral, plurilateral and bilateral, bringing together the experience of the past with the perspectives of the future. This is all the more valuable coming from the standpoint of an open, trade-dependent economy that has always been one of the strongest supporters of the multilateral principle. Singapore generously hosted the First Ministerial Conference of the WTO in 1996, and I retain warm memories of the close co-operation I enjoyed with Singaporean Ministers and Officials, many of whom, including my old friend Ambassador K. Kesavapany, have contributed to this volume.

We are living through a critical time for the multilateral trading system, one of the main pillars of the post-World War II order. The challenges facing us are both old and new, with the latter - for instance climate change or resource depletion - being perhaps the most alarming since their impact is truly global and their nature so multidimensional. And yet we do not have new policy instruments or structures to help us tackle these challenges. Worse, in some cases we are actually eroding the existing multilateral foundations, as with the proliferation of preferential trade agreements. This is not only a trade issue. It is a global economic and social scenario with disturbing political implications. A world economy based on preferences would be a very different place from the one we have known for many decades.

That is why this book is so timely. The multilateral trading system has never been more essential than it is today to the promotion of peace, development and stability. In the crisis, the WTO has proved its worth as a bulwark against protectionism. It has been instrumental in preventing things from getting even worse. The task now is to ensure it makes a positive contribution not only to economic recovery but also to the long-term global challenges. 
A clear and accurate diagnosis is the only basis for an effective remedy, and this book is a significant step in that direction. Its particular strength is to bring together academics and practitioners, intellectual depth and real-life experience. It covers all the main aspects of the trading system, always with clarity and a balanced judgement between achievements and outstanding problems. The historical presentation of the anti-dumping instrument, for example, is not only intrinsically interesting but also very relevant to maintaining a rules-based system.

In every chapter you will find an incentive for fresh thinking, which is what we urgently need. Times have changed substantially and so have the problems. The continuing unresolved problems of the Doha Round are only one aspect of the consequences of trying to move ahead without also taking account of a new agenda.

The analysis in this book of the strengths and weaknesses of the consensus principle is very important. In this connection, I would like to emphasise three points.

First, the need to add some flexibility to the way consensus operates in the WTO, without negating the fundamental principle. There have been many ideas and proposals advanced. None would be easy to implement. Perhaps one possibility is something we have already tried successfully: using plurilateral agreements to add an opting in and out dimension that would lessen the pressure created when everyone has to join the consensus at the same time. It is interesting to recall that the last substantive agreement concluded in the WTO, the Financial Services Agreement of 1997, was done on this basis.

Second, the proliferation of preferential agreements has already gone too far to be turned back. They are no longer the exception, as they were intended to be, but rather the rule. Over 400 have been notified to the WTO. And many more such agreements, covering all major trade areas, are in the pipeline - over 30 have been notified. But if it is not possible to go back, it is possible to create new incentives to bring preferential agreements into convergence with the multilateral system over time. This is another way in which to give flexibility to the consensus principle.

Third, the fuller integration with the multilateral process of the informal groupings and processes so well described in these pages would also help improve the balance between consensus and flexibility. 
One final observation: this book is a testimony to the great importance of smaller players in working for solutions and improvements in the multilateral context. Singapore is in the front row of the "friends of the system", and the multilateral system is fortunate to have such friends. I wish this work, and its authors, every success. 
This page is intentionally left blank 


\section{PREFACE}

This book is the result of collaboration between Singapore's practitioners, practitioner-scholars and scholar-practitioners. By necessity, it is interdisciplinary. In addressing the subject of Singapore's economic diplomacy, the book addresses not only the strategies and economic policies which underpin and inform economic diplomacy, but also the fact that such diplomacy is often treaty-bound and requires an appreciation of how trade rules work. Nonetheless, negotiation is its central focus and, more specifically, trade and trade-related negotiations - multilateral, plurilateral, regional, sectoral and bilateral.

Many people have contributed to the production of this book; without whose counsel, advice, criticism and frank observations we would not have had the courage to make it to print.

We thank Mr. George Yeo, Minister for Foreign Affairs, Singapore; Mr. Lim Hng Kiang, Minister for Trade and Industry, Singapore; and Mr. Khaw Boon Wan, Minister for Health and former Permanent Secretary at the Ministry of Trade and Industry, Singapore.

We are also grateful to Mr. Peter Ho, former Permanent Secretary, Ministry of Foreign Affairs, Singapore, for his support and encouragement and we are indebted to Mr. Renato Ruggiero, former Director-General of the WTO, for his kind letter which is reproduced in this book, as well as to Mr. Supachai Panitchpakdi, Secretary-General of UNCTAD, Mr. Stuart Harbinson, former Chairman of the General Council of the WTO, Mr. Tony Chew, Chairman of the Singapore Business Federation, and Professor Joel P. Trachtman of the Fletcher School of Law and Diplomacy at Tufts University, all of whom gave freely of their time to read various drafts. In the course of the book's preparation, we benefited significantly from the comments, support and advice of the editorial advisory committee, comprising Dean Barry Desker of the S. Rajaratnam School of International Studies, Ambassador Tommy Koh and Ambassador See Chak Mun of the Ministry of Foreign Affairs, Singapore, and Ambassador Ong Keng Yong of 
the Institute of Policy Studies, Singapore. Barry Desker and See Chak Mun were immensely generous in reading and offering their insightful and careful comments on the various draft chapters. Ms. Chang Li Lin of the Institute of Policy Studies provided invaluable experience and assistance in securing the publishing arrangements with World Scientific, and by shepherding the book through print. The project benefited from the support of the University of Hong Kong's Seed Funding for Basic Research Programme, and the constant encouragement of its Dean of Law, Professor Johannes M.M. Chan S.C. The Lee Kuan Yew School of Public Policy provided a home, within a remarkable institution, during the final stages of the manuscript. We are especially grateful to its Dean, Professor Kishore Mahbubani, and to Colonel Sukhvinder Singh Chopra. The World Trade Organisation has our gratitude for its permission to reproduce the mural Le travail dans l'abondance by Gustave-Louis Jaulmes. Finally, we would like to thank all our authors who not only wrote for us, but cheerfully accepted our demands despite the pressures of work. We could not have hoped for better colleagues.

C.L. Lim \& Margaret Liang

May 2010 


\title{
ABOUT THE CONTRIBUTORS
}

\begin{abstract}
David Chin Soon Siong, Executive Director, Singapore Maritime Foundation. He was formerly Director-General (Trade) at the Ministry of Trade and Industry and Deputy CEO at the Trade Development Board, Singapore.
\end{abstract}

Barry Desker, Dean, S. Rajaratnam School of International Studies and Director, Institute of Defence and Strategic Studies, Nanyang Technological University. He was CEO at the Singapore Trade Development Board from 1994 to 2000.

Michael Ewing-Chow, Associate Professor, Faculty of Law, National University of Singapore; Head, Trade Law and Policy Programme, Centre for International Law, Singapore.

Peter Govindasamy, Director, International Negotiations Division, Ministry of Trade and Industry, Singapore. Formerly Counsellor to the Singapore Permanent Mission to the WTO in Geneva.

K. Kesavapany, Director, Institute of Southeast Asian Studies. Formerly Singapore's Permanent Representative to the United Nations in Geneva and to the GATT/WTO from 28 December 1991 to 5 March 1997.

Tommy Koh, Ambassador-At-Large, Ministry of Foreign Affairs, Singapore, served as a WTO panellist in the US-Helms Burton, Canada-Dairy and USLamb disputes, and as Chairman in the latter two disputes.

Margaret Liang, Consultant to the Ministry of Foreign Affairs, Singapore; Adjunct Professor, Faculty of Law, National University of Singapore. Was formerly Singapore's Deputy Permanent Representative to the United Nations in Geneva and to the GATT/WTO. 
C.L. Lim, Chairperson, East Asian International Economic Law and Policy Programme, Professor of Law and Associate Dean for Academic Affairs, University of Hong Kong, and Visiting Professor of Law, King's College London. Formerly State Counsel, Attorney-General's Chambers on secondment from the National University of Singapore.

Vanu Gopala Menon, Singapore's Permanent Representative to the United Nations in New York. Formerly Singapore's Permanent Representative to the United Nations in Geneva and to the WTO from December 2001 to August 2004.

Ng Bee Kim, Director-General, Trade Division, Ministry of Trade and Industry, Singapore.

Ong Ye Kung, Assistant Secretary-General of the National Trades Union Congress and Chairman of the Employment and Employability Institute, Singapore. He was formerly Singapore's Deputy Chief Negotiator for the US-Singapore FTA, and Director (Trade) at the Ministry of Trade and Industry, Singapore.

Minn Naing Oo, CEO and Registrar, Singapore International Arbitration Centre.

Pang Kin Keong, Permanent Secretary, Ministry of Law; formerly Director, Ministry of Home Affairs, Principal Private Secretary to Prime Minister Goh Chok Tong, and Deputy Secretary (Special Projects), Ministry of Trade and Industry, Singapore.

See Chak Mun was Singapore's Permanent Representative to the United Nations in Geneva and to the GATT/WTO from 1986-1991 and from 1997-2001.

S. Tiwari was Visiting Senior Research Fellow, Institute of Southeast Asian Studies, Singapore and formerly Principal Senior State Counsel and Head of the International Affairs Division, Attorney-General's Chambers, Singapore.

Geoffrey Yu, formerly Senior Specialist Advisor, Ministry of Foreign Affairs and Ministry of Law, Singapore. Formerly Deputy Director-General, World Intellectual Property Organisation. 